\title{
Empreendedorismo orientado para a sustentabilidade: as inovações no caso da Volkmann
}

\section{Entrepreneurship oriented towards sustainability: the innovations in the Volkmann's case}

\author{
Natalia Aguilar Delgado ${ }^{1}$ \\ Luciano Barin Cruz \\ Eugenio Avila Pedrozo ${ }^{3}$ \\ Tania Nunes da Silva ${ }^{4}$
}

\section{Resumo}

Alguns autores apontam o empreendedorismo como um importante vetor de sustentabilidade socioeconômica nos países do mundo inteiro. No entanto, acredita-se que o papel do empreendedor pode ir além desses fatores socioeconômicos observados por estes autores. Com uma mudança de valores, se poderia constituir uma nova noção de empreendedorismo orientado para a sustentabilidade também ambiental, sendo essa a discussão central deste artigo. Tendo em vista a constatação de que os produtos advindos de práticas agrícolas biodinâmicas podem ser considerados social e ambientalmente corretos, pretende-se, neste artigo, analisar as inovações desenvolvidas por um empreendedor que é um dos principais produtores de arroz biodinâmico brasileiro. Neste artigo, se assume uma abordagem qualitativa visando captar, com maior profundidade, detalhes relacionados ao caso desse empreendedor. Entende-se que, além de criatividade e liderança, o empreendedor orientado para a sustentabilidade deve possuir valores que estejam de acordo com essa perspectiva ao conduzir as atividades da organização.

Palavras-chave: Empreendedorismo, Desenvolvimento Sustentável, Inovação, Agricultura Biodinâmica.

\begin{abstract}
Some authors point the entrepreneurship as an important vector of social and economical sustainability in the countries all around the world. However, we believe that the role of the entrepreneur can go beyond these factors observed by these authors. Starting from a change of values, they could constitute a new notion of entrepreneurship oriented, also, towards environmental sustainability, being this the main discussion of this article. Taking into account that the biodynamic products can be considered socially and environmentally correct, we intend to analyze, in this article, the innovations developed by an entrepreneur who is one of the main producers of biodynamic rice in Brazil. This article assumes a qualitative boarding aiming to catch, in a deeper way, details related to the case of this entrepreneur. We understand that, beyond creativity and leadership, the entrepreneur oriented towards sustainability must possess values that are in accordance with this perspective when leading the activities of the organization.
\end{abstract}

Keywords: Entrepreneurship, Sustainable Development, Innovation, Byodinamic Agriculture.

\footnotetext{
${ }^{1}$ Mestre em Administração de Empresas pela Universidade Federal do Rio Grande do Sul. Professora Auxiliar do Centro de Ciências Administrativas da UNIFOR Endereço: Av. Washington Soares, 1321 - Bloco N - Fortaleza - Ceará - CEP: 60811-905 Email: nadelgado@unifor.com.br

${ }^{2}$ Doutor en Science de Gestion na Université Jean Moulin Lyon III (França) e Doutor em Administração de Empresas pela Universidade Federal do Rio Grande do Sul. Professor Adjunto (Mestrado em Administração - CMA) da UNIFOR Endereço: Av. Washington Soares, 1321 - Bloco Q, Sala 3 - Fortaleza - Ceará - CEP: 60811-905 - E-mail: Ibarincruz@unifor.br

${ }^{3}$ Doutor Institut Nationale Polytechnique de Lorraine (INPL)- Nancy, França Professor Adjunto PPGA/EA E PPG-Agronegócios/CEPAN da UFRGS. Endereço: Rua Washington Luis, 855 - Sala 412 - Centro - Porto Alegre/Rio Grande do Sul - Brasil - CEP: 90010-460 - Email: eapedrozo@ea.ufrgs.br

${ }^{4}$ Doutora em Sociologia do Desenvolvimento (USP) Professora Adjunto 4 da Universidade Federal do Rio Grande do Sul- UFRGS(PPG-Administração e PPGAgronegócios). Endereço: Rua Washington Luis, 855 - Centro - Porto Alegre/Rio Grande do Sul - Brasil - CEP: 90010460 - Email: tnsilva@ea.ufrgs.br Artigo submetido em julho de 2007 e aceito em fevereiro de 2008
} 


\section{Introdução}

Alguns autores apontam o empreendedorismo como um importante vetor de sustentabilidade socioeconômica nos países do mundo inteiro, dos mais aos menos desenvolvidos (SCHUMPETER, 1934; SHANE, 1995; SHANE; VENTAKARAMAN, 2000; RIMOLI et al., 2004; SALES; SOUZA NETO, 2004; GLOBAL ENTREPRERNEURSHIP MONITOR, 2006). No entanto, acredita-se que o papel do empreendedor pode ir além dos fatores socioeconômicos observados por estes autores. Uma mudança de valores poderia constituir uma nova noção de empreendedorismo orientado para a sustentabilidade também ambiental, sendo essa a discussão central deste artigo.

Dados os problemas econômicos, sociais e ambientais que assolam o planeta atualmente, o desenvolvimento sustentável é campo de vasto debate. Percebe-se a emergência da necessidade da construção de uma economia em que os recursos ambientais e as necessidades da sociedade como um todo estejam em equilíbrio, sem, no entanto, comprometer as futuras gerações (WORLD COMISSION ON ENVIROMENT AND DEVELOPMENT, 1987).

Por se tratar de uma atividade econômica que lida diretamente com o meio ambiente, é aconselhável que a agricultura seja tratada de uma perspectiva de desenvolvimento sustentável (SACHS, 2001; 2002; 2004). Diretamente relacionada à agricultura, está a agroindústria, foco, hoje, de preocupação mundial, uma vez que a taxa populacional cresce a cada dia e que o "uso de recursos naturais, tais como água e terra, tem sido um dos grandes vetores de pressão sobre a biodiversidade" (FELDMANN, 2003, p. 144). Nesse sentido, na contramão da chamada agricultura 'convencional' (baseada na utilização de insumos químicos e alta mecanização), observa-se a crescente tendência ao consumo e à produção de produtos cultivados de forma alternativa (biodinâmicos, agroecológicos, orgânicos, entre outros), em que, de forma geral, preconiza-se a não utilização de insumos químicos e sintéticos nas práticas agrícolas.

Além dessa questão mais ligada à dimensão ambiental, Veiga (2001) destaca, ainda, algumas dificuldades socioeconômicas que envolvem o mundo rural. Ele afirma que, para que muitas empresas e muitos empregos possam ser criados em regiões com predomínio da agricultura familiar, faz-se necessário um mínimo de condições favoráveis que estimulem o empreendedorismo. Afinal, segundo o autor, são os empreendedores os principais agentes da mudança econômica, pois são eles que, ao procurar identificar as potenciais oportunidades de negócios e assumir os riscos de suas apostas, contribuem tanto para um maior uso dos recursos disponíveis, quanto para a expansão das fronteiras da atividade econômica. Logo, sejam os empreendedores do meio rural ou urbano, têm ainda importante papel na geração, disseminação e aplicação de inovações (SCHUMPETER, 1934; PENROSE, 1959; JACOBSON, 1992; LUMPKIN, DESS, 1996; GLOBAL ENTREPRENEURSHIP MONITOR, 2006).

Tendo em vista a importância do empreendedorismo no meio rural e a constatação de que os produtos advindos do cultivo alternativo poderiam estar alinhados aos princípios da sustentabilidade, pretende-se, neste estudo, analisar as práticas de um empreendedor rural orientado para a sustentabilidade, relacionando-as com as inovações geradas por ele - um dos pioneiros e dos principais produtores de arroz biodinâmico no Brasil.

Considerando a complexidade do tema e entendendo a atualidade e a relevância do mesmo para a sociedade, este artigo assume uma abordagem qualitativa (conforme sugere TRIVIÑOS, 1987) com o objetivo de captar, com maior profundidade, detalhes relacionados ao caso desse empreendedor rural. Para tanto, utilizam-se dados obtidos por meio de fonte secundária (pesquisa na internet) e primária (entrevista com o empreendedor da fazenda produtora).

Dessa forma, num primeiro momento, são discutidos alguns conceitos de empreendedorismo. Num segundo momento, aponta-se a distinção entre agricultura convencional e agricultura orientada para sustentabilidade, destacando-se as características da agricultura biodinâmica. Num terceiro momento, expõe-se a interface existente entre inovação e desenvolvimento sustentável. A seguir, faz-se a apresentação do estudo de caso (conforme sugere YIN, 2005) com um dos principais produtores de arroz biodinâmico do Brasil, no sentido de 
desvendar alguns aspectos que envolvem o empreendedorismo voltado para sustentabilidade e como isso se transpõe para as suas práticas organizacionais.

\section{0 papel do empreendedorismo}

O campo de estudo sobre empreendedorismo vem sendo cada vez mais explorado nos últimos anos (RODRIGUES; VIEIRA, 2004). Pode-se dizer que existem algumas temáticas mais recorrentes nesse campo, tais como: as características e a tipologia do empreendedor (LAFUENTE; SALAS, 1989; FILION, 1999; FILION, 2000; EGRI; HERMAN, 2000; DE KLERK; KRUGER, 2006; MACHADO et al. 2003; SALES; SOUZA NETO, 2004; GLOBAL ENTREPRENEURSHIP MONITOR - GEM, 2006); as motivações do empreendedor (MACHADO et al. 2003; RODRIGUES; VIEIRA, 2004; GLOBAL ENTREPRENEURSHIP MONITOR, 2006) e finalmente; os fatores de sucesso e insucesso dos empreendimentos (JO; LEE, 1996; MILLER; MORRIS, 1999; DE KLERK; KRUGER, 2003; RIMOLI et. al. 2004; SOUZA DUTRA, 2004; GLOBAL ENTREPRENEURSHIP MONITOR, 2006). Neste artigo serão exploradas as características e as motivações do empreendedor. Entretanto, acredita-se ser importante primeiramente situar o contexto brasileiro em termos de potencial para o empreendedorismo.

Segundo relatório da Global Entrepreneurship Monitor ${ }^{1}$ (2006), o Brasil está entre as nações onde mais se criam negócios, com uma taxa de empreendedores iniciais ${ }^{2}$ de $11,3 \%$ (percentual da população adulta entre 18 e 64 anos), situando-se na sétima colocação entre os participantes. Esse mesmo relatório levanta alguns dados relevantes à compreensão de como se dá o empreendedorismo no Brasil.

Em linhas gerais, a probabilidade de sobrevivência, ou seja, de os negócios em estágio inicial tornarem-se estabelecidos, é maior em países de renda mais alta do que nos de renda média. O Brasil, espelhando essa constatação, possui a $14^{\mathrm{a}}$ maior razão entre empreendedores estabelecidos e em estágio inicial. Entretanto, o comportamento desse indicador vem melhorando no país ao longo dos últimos anos, o que pode significar uma acomodação na dinâmica de criação de novos negócios ou uma melhoria nas condições para que um maior número de negócios sobreviva por períodos mais longos.

Embora a maioria dos empreendedores seja orientada pela oportunidade, a presença daqueles que empreenderam por necessidade é bastante alta se comparada à maioria dos países participantes do GEM. O Brasil ocupa a $15^{\text {a }}$ posição no ranking do empreendedorismo por oportunidade e a $4^{\mathrm{a}}$ posição no ranking de empreendedorismo por necessidade. Portanto, evidencia-se a influência do empreendedorismo por necessidade na posição do Brasil em relação aos demais países.

Com relação à inovação, o uso de tecnologias disponíveis há menos de um ano pelos empreendedores brasileiros é menor do que nos outros países de semelhante nível de renda. No Brasil, 97,4\% dos empreendedores iniciais e $98,6 \%$ dos estabelecidos afirmam utilizar tecnologias ou processos conhecidos há mais de um ano. No conjunto dos países de média renda, estes grupos de empreendedores somam, respectivamente, $70 \%$ e $80 \%$. Isso se deve ao fato de que, quando se considera a totalidade da população empreendedora brasileira, a grande maioria opta por abrir negócios com baixo nível de inovação - seja tecnológica ou de mercado. De outra parte, isso pode dar uma indicação dos obstáculos enfrentados pelos empreendedores para manter seus negócios por maiores períodos de tempo.

Esses dados confrontam-se com a proposição de Schumpeter (1934), para quem o empreendedor teria papel preponderante na criação e implementação de inovações tecnológicas e gerenciais, sendo dotado de características que proporcionariam atitudes inovadoras que viriam a quebrar o equilíbrio e a inércia do mercado, e com a descontinuidade dos processos, gerariam períodos de prosperidade econômica. Assim, o empreendedor poderia ser caracterizado como elemento essencial, senão único, capaz de propor e introduzir inovações que viriam a criar prosperidade e riqueza no contexto econômico. 
Shane e Ventakaraman (2000) afirmam que, nesse particular, há debates em aberto no campo de estudo do empreendedorismo. Eles questionam se o conceito de "empreendedor como alguém que abre um novo negócio" não seria insuficiente para explicar os fatores individuais e o contexto onde o mesmo está inserido. Logo, os autores propõem a elaboração de um framework para o empreendedorismo calcado no nexo entre dois fenômenos: a existência de oportunidades e a presença de pessoas empreendedoras.

De Klerk e Kruger (2003) realizaram um resgate histórico das visões de alguns autores, destacando as principais características que determinam o empreendedorismo: prontidão, visão do futuro, capacidade de assumir riscos, capital suficiente, conhecimento suficiente, discernimento, criatividade, inovação, ambição, visão, firmeza, determinação, dedicação, valor(es), adaptabilidade e recompensa.

Filion (2000) também enumera algumas características de empreendedores bem-sucedidos: valores e cultura de empreendedorismo adquiridos por meio de contato com, pelo menos, um modelo empreendedor durante a juventude; experiência em negócios; diferenciação; intuição; envolvimento; capacidade de trabalhar incansavelmente; Sonhadores realistas (visionários); liderança; trabalho em rede com moderação; sistema próprio de relações com os empregados; controle do comportamento das pessoas ao redor; aprendizagem dos próprios padrões.

O mesmo autor destaca ainda algumas características distintivas entre empreendedores e gerentes-proprietários de suas organizações, conforme se apresenta no Quadro 1.

\section{Quadro 1: Diferenças nos sistemas de atividades de gerentes e empreendedores}

\begin{tabular}{ll}
\hline Gerentes & Empreendedores \\
\hline $\begin{array}{l}\text { Trabalham com a eficiência e o uso efetivo } \\
\text { dos recursos para atingir metas e objetivos. }\end{array}$ & $\begin{array}{l}\text { Estabelecem uma visão e objetivos e identificam os } \\
\text { recursos para torná-los realidade. }\end{array}$ \\
\hline A chave é adaptar-se às mudanças. & A chave é iniciar as mudanças. \\
\hline O padrão de trabalho implica análise racional. & $\begin{array}{l}\text { O padrão de trabalho implica imaginação e } \\
\text { criatividade. }\end{array}$ \\
\hline Operam dentro da estrutura de trabalho existente. & $\begin{array}{l}\text { Definem tarefas e funções que criem uma estrutura } \\
\text { de trabalho. }\end{array}$ \\
\hline $\begin{array}{l}\text { Trabalho centrado em processos que levam em } \\
\text { consideração o meio em que ele se desenvolve. }\end{array}$ & $\begin{array}{l}\text { Trabalho centrado na criação de processos } \\
\text { resultantes de uma visão diferenciada do meio. }\end{array}$ \\
\hline
\end{tabular}

Fonte: Filion (p. 3, 2000).

Dessa forma, percebe-se que a atividade empreendedora não se desvincula dos planos de vida da pessoa em sua energia para empreender (RODRIGUES; VIEIRA, 2004). Qualquer que seja seu motivo para empreender, sua rede de relacionamentos ou outras formas de mediação social, em algum momento as atividades empresariais interceptam o alinhamento daquelas de cunho particular.

Relacionando essas questões a liderança e sustentabilidade, Egri e Herman (2000) buscam encontrar características comuns a líderes 'ambientais', sejam eles de associações, ONG's ou organizações que têm como premissa, em sua atividade, o respeito ao meio-ambiente. Para eles, o conceito de 'liderança ambiental' seria a habilidade de influenciar indivíduos e mobilizar organizações a realizar uma visão de sustentabilidade em longo prazo. Guiados por valores e premissas pessoais, esses líderes buscam mudança nos sistemas socioeconômicos que eles percebem como potencialmente danosos para a saúde do ambiente biofísico.

Os autores destacam, também, que, de acordo com o sistema tradicional, o ambiente biofísico está a serviço da humanidade, como fonte de matérias-primas e energia ou como depósito para os desperdícios. Em contraste, de acordo com um sistema ecocêntrico, a relação homem-natureza é interdependente, compreende dimensões físicas, socioeconômicas e, inclusive, espirituais. O processo de tomada de decisão nas organizações, dentro 
dessa última perspectiva, incorporaria a sustentabilidade como o elemento primordial na construção da missão e dos valores organizacionais.

O que transparece nessa breve discussão é a importância das características e valores pessoais do empreendedor, alinhadas com as oportunidades e as práticas que conduzem ao alcance dos resultados nas suas organizações. Visando atender aos objetivos propostos, a revisão prossegue com a abordagem de alguns temas diretamente ligados à agricultura e à sustentabilidade, duas questões que envolvem a trajetória do empreendedor cujo caso será apresentado.

\section{A agricultura convencional e o paradigma da sustentabilidade}

A partir da década de 1960, vários países latino-americanos engajaram-se na chamada 'Revolução Verde', fundada basicamente em princípios de aumento da produtividade por meio do uso intensivo de insumos químicos, de variedades de alto rendimento melhoradas geneticamente, da irrigação e da mecanização - assim, criou-se a idéia que passou a ser conhecida com freqüência como aquela do 'pacote tecnológico'. Vários problemas, entretanto, ocorreram nesse período, especialmente no que tange à desigualdade social e à sustentabilidade (econômica e ecológica) da produção agrícola no longo prazo (ALMEIDA, 1997). Como salienta Navarro (2001, p. 84), essa revolução rompeu radicalmente com o passado, por integrar fortemente as famílias rurais a novas formas de racionalidade produtiva, quebrando a relativa autonomia setorial que em outros tempos a agricultura experimentara.

No entanto, essa revolução teve também seu impacto no meio-ambiente. O uso abusivo de herbicidas, fertilizantes e agrotóxicos sintéticos, além das práticas monocultoras, configura-se atividade que acaba levando a erosão dos solos, poluição da água e contaminação de alimentos.

Por um lado, os defensores dessas práticas argumentam que esse modelo constitui a forma ideal de manter níveis suficientes de produtividade de alimentos para satisfazer a população mundial, que cresce a cada ano. Em contrapartida, alguns pesquisadores alertam para o engano contido nesse argumento, pois o conhecimento atual permite uma agricultura avançada "sem a necessidade de atividades monoculturas, altamente mecanizadas e [...] fertilizantes comerciais e venenos sintéticos" (LUTZENBERGER, 2001, p. 61).

Exemplificando essa situação, Hawken et al. (1999, p. 182) afirmam que atualmente os Estados Unidos gastam vinte vezes mais em inseticidas (totalizando quase 400 milhões de quilos por ano). Ainda assim, ocorre uma perda, da safra, de seis por cento a mais (totalizando treze por cento) em relação ao inicio dos anos 1950.

O Brasil, país de destaque mundial em termos de agronegócios, comete consecutivos erros estratégicos, ao não considerar a sustentabilidade do setor, em termos ambientais, econômicos e sociais (SACHS, 2001). Os grandes produtores mostram-se adeptos de práticas fortemente mecanizadas e monocultoras, que vêm destruindo a diversidade dos solos e das espécies vegetais.

Tendo em vista o exposto, surgem modelos de uma agricultura sustentável que têm como objetivo: "o manejo eficiente dos recursos disponíveis, mantendo a produção nos níveis necessários para satisfazer às crescentes aspirações de uma também crescente população, sem degradar o meio ambiente" (PATERNIANI, 2001, p. 303). Percebe-se, paralelamente, uma mudança nos hábitos de consumo de alimentos, principalmente em países mais desenvolvidos, na medida em que o consumidor tem maior liberdade de escolha de mercadorias, passando a cobrar, além de melhores preços, uma postura diferenciada das organizações frente a questões emergentes, como rotulagem, segurança dos alimentos, comprometimento ambiental, produção limpa, embalagens recicláveis, abate sem dor, trabalho infantil, entre outros (FERREIRA et al., 2005). Nesse sentido, Pedrozo, Silva e Takitane (2004) destacam que a maneira como os alimentos são produzidos causa impactos no meio ambiente e na saúde das pessoas e, por isso, novas estratégias emergem para tratar da segurança dos alimentos. Elas não são somente baseadas em fatores econômicos ou organizacionais, mas, também, em novos padrões de consumo de alimentos, com ênfase em características de desenvolvimento sustentável. 
Analisando a definição de desenvolvimento sustentável da World Comission on Enviroment and Development (WCED, 1987), a qual seria "o conjunto de ações que promove a satisfação das necessidades das gerações presentes sem comprometer as possibilidades das gerações futuras", percebe-se que esse é um discurso extremamente alinhado com o movimento de agricultura sustentável e em particular da agricultura biodinâmica.

A Alemanha, berço da química agrícola, foi também o berço da mais antiga reação, cristalizada em 1924, disseminada como biodinâmica. Esse movimento teve como figura central o filósofo Rudolf Steiner, cujas idéias alicerçaram a investigação de várias gerações de agrônomos e agricultores. O motivador imediato dos agricultores que buscaram esse novo método estava no rápido declínio das lavouras e nas criações submetidas à tecnologia de ponta, centradas, até então, nos adubos químicos. Nesse método, preconiza-se a abordagem sistêmica, entendendo a propriedade rural como um organismo (KHATOUNIAN, 2001).

Ávila (2000) destaca alguns pontos essenciais da biodinâmica. A estruturação da fazenda deve ser vista como um organismo integrado, diversificado, auto-sustentável, em que os diversos setores se complementam e se apóiam mutuamente, vindo a constituir, com o tempo, um ciclo fechado de nutrientes, com a compra de insumos reduzida gradativamente a um mínimo, tendendo a zero. Nesse organismo, também o ser humano deve ser integrado à unidade produtiva, pois o ambiente social que impera na fazenda é fator de suma importância.

Para atingir o ideal de aporte mínimo de insumos externos, o agricultor busca em primeiro lugar otimizar o aproveitamento dos recursos locais - plantações e pastagens que fornecem a ração dos animais, produzindo alimento para o homem, e excrementos, os quais geram o húmus, um fertilizante orgânico ideal para o solo. Outra característica é o respeito pelos ciclos naturais, pois a planta cumpre o seu ciclo e, ao final, fornece sais, vitaminas, proteínas capazes de verdadeiramente nutrir (ÁVILA, 2000).

Algumas das práticas da biodinâmica não são usuais para grande parte dos agricultores, o que se reflete na utilização de algumas terminologias pouco conhecidas, tais como 'preparados biodinâmicos' ou 'força vital'. Os 'preparados biodinâmicos' ocupam o cerne de todo o sistema. É condição para o uso da marca registrada DEMETER - que identifica, mundialmente, os produtos biodinâmicos e faz parte de uma rede ecológica internacional ligada ao Demeter International, sediado na Alemanha - Instituto Biodinâmico, 2006. Aplicados em doses mínimas, ativam a 'força vital' do solo e das plantas, estabelecendo uma sintonia entre a terra e o cosmos (ÁVILA, 2000). Todas essas práticas podem se tornar um verdadeiro vetor de sustentabilidade para o agricultor, o meio-ambiente e a sociedade como um todo.

Dessa forma, na busca do equilíbrio entre a proteção ao meio-ambiente e às necessidades dos empreendedores que trabalham no contexto de um mercado extremamente competitivo, as inovações podem ter importante papel, conforme se explanará a seguir.

\section{0 papel da inovação na sustentabilidade}

Neste artigo, definimos inovação como qualquer alteração efetuada na gestão, no produto, no processo ou no equipamento produtivo, que se constitua em novidade para a organização, ainda que já divulgada e difundida no setor (MACHLINE, 1978; DAMANPOUR, 1984; KLEIN; SORRA, 1996). Dessa forma, as inovações, no sentido aqui usado, serão efetivamente constituídas de implantação de descobertas de domínio comum.

Quando se fala em inovação, percebe-se que a dimensão econômica é comumente assinalada como central. No entanto, como observam Daroit e Nascimento (2004), no lugar de se ater apenas ao atendimento das demandas do mercado, a geração de inovações voltadas para a sustentabilidade teria que considerar os valores e necessidades da sociedade, visando seu bem-estar tanto financeiro quanto o relativo à qualidade de vida. 
Nesse sentido, Gladwin, Kennelly e Krause (1995) apresentam uma classificação de três paradigmas que examinam a relação homem/natureza: paradigma tecnocêntrico, paradigma ecocêntrico e sustaincentric paradigm. O primeiro é o dominante e suporta a idéia de que a Terra é inerte e passiva, podendo ser, portanto, legitimamente explorada. A ética é antropocêntrica, egoísta e utilitarista, porque o que mais importa são os seres humanos contemporâneos. Todos os problemas podem ser resolvidos por meio da tecnologia. O segundo paradigma promove uma visão da biosfera e da sociedade baseadas nos princípios ecológicos do holismo, do equilíbrio da natureza, da diversidade, dos limites finitos e das mudanças dinâmicas. Da perspectiva de que a natureza é frágil e vulnerável, há uma visão pessimista da tecnologia, pois não se acredita que o ser humano tenha capacidade de usá-la de forma sábia. A terceira vertente, também defendida pelos autores, é chamada de sustaincentric paradigm. Segundo os autores, esta perspectiva incorporaria uma noção conciliatória e ampliada para as diversas dimensões que fazem parte da noção de sustentabilidade. Aceita-se que o ecossistema global é finito, vulnerável à interferência humana e limitado em sua capacidade regenerativa. Basicamente, desta perspectiva busca-se avaliar o impacto ecológico, social e econômico de novas tecnologias, antes que elas sejam introduzidas, com o objetivo de minimizar seus efeitos adversos.

Bartholo (2001, p. 20) corrobora a visão do terceiro paradigma (sustaincentric paradigm) ao afirmar:

O desenvolvimento sustentável requer um acervo de conhecimentos e de habilidades de ação para a implementação de processos tecnicamente viáveis e eticamente desejáveis. Tal acervo são as tecnologias da sustentabilidade, que podem ser caracterizadas como saberes e habilidades de perenização da vida. As tecnologias da sustentabilidade dizem respeito tanto a processos de produção e circulação do produto como a modos de organização social, padrões de ganho e processamento de informações.

Entretanto, não somente os padrões de produção devem mudar, mas também os de consumo. O papel do consumidor dentro de um paradigma de sustentabilidade é fundamental, pois é este mesmo agente que valida os produtos e serviços das indústrias no mercado e que sofrerá as conseqüências nefastas da continuidade do paradigma economicista atual.

Segundo Hall e Vredenburg (2003), para que as inovações estejam alinhadas com o desenvolvimento sustentável, devem incorporar as restrições trazidas pelas pressões sociais e ambientais, assim como considerar as gerações futuras. Dessa forma, essas inovações são mais complexas - porque devem atender a um número maior de stakeholders, conforme definição de Freeman, 1984 - e mais ambíguas - pois as partes envolvidas podem ter demandas contraditórias. Assim, existe a necessidade de uma reflexão mais profunda sobre a criação de inovações e o papel do empreendedor que as implementa, tendo como pressuposto o paradigma do desenvolvimento sustentável.

A seguir apresentam-se os procedimentos metodológicos e o caso de uma organização dirigida por um empreendedor que busca incorporar elementos do desenvolvimento sustentável em seu processo de criação de inovações.

\section{Procedimentos Metodológicos}

Nesta pesquisa, com o intuito de atingir o objetivo já apresentado, adotou-se uma abordagem qualitativa direta, de caráter exploratório e descritivo. A seguir são apresentadas as definições desses conceitos, de forma a justificar a sua adoção.

Godoy (1995) define que, de uma perspectiva qualitativa, um fenômeno pode ser mais bem compreendido no contexto em que ocorre e do qual é parte, devendo ser analisado numa perspectiva integrada. Para tanto, o pesquisador vai a campo buscando 'captar' o fenômeno em estudo com base na perspectiva das pessoas nele envolvidas, considerando os pontos de vista relevantes. 
Para Malhotra (2001) existem duas abordagens de pesquisa qualitativa: a direta e a indireta. Segundo o autor, a abordagem direta é aquela em que os objetivos do projeto ou são revelados aos respondentes ou são óbvios pela natureza da pesquisa. A abordagem indireta é aquela em que se disfarçam os objetivos do projeto ao respondente. Como os objetivos da pesquisa foram revelados ao respondente desde o início, foi utilizada a abordagem direta nesta pesquisa.

Gil (1999) classifica o tipo de pesquisa em três grupos: estudos exploratórios, descritivos e explicativos. Os estudos exploratórios têm como principal finalidade desenvolver, esclarecer e modificar conceitos e idéias, tendo em vista a formulação de problemas mais precisos ou hipóteses pesquisáveis para estudos posteriores. Pesquisas exploratórias são desenvolvidas com o objetivo de proporcionar visão geral, do tipo aproximativo, acerca de determinado fato, podendo constituir a primeira fase de uma pesquisa mais ampla - caso da presente pesquisa em sua primeira fase, que será detalhada na próxima subseção. Nas pesquisas descritivas, o objetivo primordial é a descrição das características de determinada população ou fenômeno ou o estabelecimento de relação entre as variáveis - caso também da presente pesquisa em sua segunda fase. Já nas pesquisas explicativas, a preocupação central é identificar os fatores que determinam ou que contribuem para a ocorrência dos fenômenos, buscando explicar o porquê das coisas. Sendo assim, esta pesquisa caracteriza-se como um estudo exploratório e descritivo.

Dessa forma, diante dos objetivos que foram traçados para esta pesquisa, optou-se por conduzi-la segundo as características anteriormente apresentadas, utilizando-se a técnica de estudo de caso, conforme sugere Yin (2005). Estudos de caso são investigações empíricas que investigam um fenômeno contemporâneo dentro de seu contexto da vida real (YIN, 2005). A escolha dessa estratégia deve-se ao poder diferenciador que apresenta: capacidade de tratar com uma variedade ampla de evidências. $\mathrm{O}$ mesmo autor indica que pesquisas de estudos de caso podem ser tanto de estudos de caso único quanto de casos múltiplos. O projeto de caso único é justificável sob certas condições - quando o caso representa um teste crucial da teoria existente; uma circunstância rara ou exclusiva; um caso típico ou representativo; quando é revelador ou longitudinal. O caso apresentado pode ser visto, dentro do setor, como algo bastante raro, pois se trata de uma exceção à predominância das práticas agrícolas 'tradicionais', que utilizam insumos químicos. Além disso, a estrutura da organização estudada também se diferencia da tradicional, uma vez que o empreendedor concentra as diversas atividades gerenciais e operacionais da fazenda. E mesmo por não ser de grande porte, o empreendedor acumula funções, sendo responsável pelas estratégias de ação adotadas.

Tendo sido utilizados dados primários e secundários, os primeiros foram coletados através da realização de entrevista agendada na organização selecionada. Justifica-se a consecução de uma única entrevista por se considerar que o proprietário é o grande promotor dos processos de sustentabilidade na organização em que atua, sendo assim a principal fonte de informações necessárias para o alcance do objetivo deste artigo.

Como dados secundários, foram realizadas consultas bibliográficas a sites de internet, a revistas específicas e demais fontes que contribuíram para o alcance do objetivo estabelecido. O roteiro de perguntas foi elaborado à luz da revisão da literatura selecionada. Por meio da entrevista com o proprietário-empreendedor - duração aproximada de 3 horas, gerando 15 páginas de transcrição literal -, da pesquisa documental e da observação em visita feita no mês de janeiro de 2006 -, foi possível coletar os dados necessários e analisá-los de forma qualitativa sob a forma descritivo-interpretativa (TRIVIÑOS, 1987). A utilização dessas três fontes é chamada de 'técnica de triangulação na coleta de dados', e tem por objetivo básico abranger a máxima amplitude na descrição, explicação e compreensão do foco em estudo (TRIVIÑOS, 1987). A triangulação de dados é um processo de múltiplas percepções, em que as várias fontes são utilizadas para tornar claras as idéias, tendo em vista a repetição de interpretações e observações (STAKE, 2000).

Inicialmente faz-se uma breve descrição do mercado no qual a organização se insere. Posteriormente, apresentam-se a história da fazenda, o principal produto comercializado e o compromisso de difusão da biodinâmica. Por fim, analisam-se as inovações implementadas na fazenda, discutindo-se ainda o papel do empreendedor orientado, nesse processo, para a sustentabilidade. 


\section{Estudo de caso: empreendedorismo no caso da Volkmann, Arroz Biodinâmico}

Nesta seção, apresenta-se a reflexão sobre os aspectos teóricos, apresentados até o momento, relativos ao caso selecionado, isto é, a realidade da Volkmann, Arroz Biodinâmico.

\section{Cenário do Mercado de Arroz Brasileiro}

O arroz é considerado pela Food and Agriculture Organization of the United Nations (FAO) o alimento mais importante para a segurança alimentar do mundo. Além de fornecer um excelente balanceamento nutricional, é uma cultura extremamente rústica, o que a faz, também, ser considerada a espécie de maior potencial de aumento de produção para o combate da fome no mundo (BARATA, 2005). Assim como a produção, o consumo de arroz no mundo concentra-se nos paises do sudeste asiático, em torno 85,2 kg/hab/ano (FAO, 2006). O consumo per capita de arroz nos países em desenvolvimento é muito superior ao dos países considerados desenvolvidos (69,8 kg/hab/ano contra 11,3 kg/hab/ano). Segundo dados da FAO (2006), o consumo brasileiro de arroz beneficiado é de aproximadamente $35,0 \mathrm{~kg} / \mathrm{hab} / \mathrm{ano}$, inferior ao consumo mundial médio por habitante $(57,3 \mathrm{~kg} / \mathrm{hab} / \mathrm{ano})$.

O arroz no Brasil é cultivado em dois ecossistemas, várzeas e terras altas. O ecossistema de várzeas representou, na safra de 2002/03, aproximadamente $42 \%$ da área total sob a cultura, com 3,2 milhões de ha, contribuindo com $66 \%$ da produção de 10,2 milhões de toneladas. Nesse ecossistema predomina o sistema de cultivo com irrigação controlada, que ocupa cerca de 1,1 milhão de hectares na região subtropical (RS e SC), onde a cultura é manejada sob alto nível tecnológico e apresenta rendimento médio de 5,2t/ha. A produção convencional no RS é altamente mecanizada, ocorre em áreas sistematizadas, onde a semeadura é feita em solo seco e a água é manejada na forma de banhos (EMBRAPA ARROZ E FEIJÃO, 2006).

Dados do IBGE de 2004 mostram que o Brasil produziu em torno de 13.277.008 t de arroz, e que o Rio Grande do Sul foi responsável por quase metade dessa quantidade (6.338.139 ton.). A maior área plantada de arroz encontra-se no Rio Grande do Sul, que fica em segundo lugar em termos de produtividade $(5.912 \mathrm{~kg} / \mathrm{ha})$, atrás apenas do estado de Santa Catarina (CONAB, 2006).

Segundo Mello (1996 apud LUDWIG, 2004), esta alta produtividade de arroz irrigado no RS deve-se a uma elevada utilização de tecnologia aplicada às lavouras arrozeiras, como por exemplo, modernos sistemas de irrigação, sementes de alta qualidade etc. Os níveis de produtividade do arroz-riograndense podem ser comparados aos dos maiores produtores mundiais.

O Rio Grande do Sul, além de ser o maior produtor de arroz do Brasil, o é também como industrializador nacional, contando com o maior parque agroindustrial para o processamento deste produto. As características dos engenhos de beneficiamento que absorvem a produção são bastante diversificadas: podem ocorrer da maneira mais simples e tradicional até a utilização de processos mais modernos, como seleção eletrônica, padronização e ensacamento final com destino aos supermercados. Estes engenhos possuem marca própria ou são prestadores de serviços para que terceiros coloquem a marca (LUDWIG, 2004).

Nas condições brasileiras, o arroz é consumido, principalmente, na forma de grãos inteiros. É classificado em três tipos de produto, de acordo com a forma de processamento: beneficiado polido, parboilizado e integral. $\mathrm{O}$ primeiro é a forma predominantemente consumida na maioria das regiões brasileiras e é obtido por meio do descasque e do polimento do grão integral. O arroz parboilizado é aquele que, ainda em casca, é submetido a um processo hidrotérmico que provoca a gelatinização total ou parcial do amido, passando, posteriormente, pelo descasque e pelo polimento. $\mathrm{O}$ arroz integral é produto do qual, no processo de beneficiamento, é retirada apenas a casca. Este último, embora seja mais rico em nutrientes do que o arroz polido, é pouco consumido no Brasil (EMBRAPA ARROZ E FEIJÃO, 2006).

O arroz, produto da orizicultura convencional, pode ser classificado como commodity, pois pode ser padronizado, possui baixo valor agregado, pode ser comprado e vendido em bolsas de mercadorias, além de o 
seu preço ser altamente influenciado por questões políticas e econômicas, o que por sua vez tem influência direta em seu consumo (DEON, 2002).

Ludwig (2004) afirma que, para lhe agregar valor, existem algumas alternativas, tais como vender o produto como orgânico ou ecológico; possuir um selo verde ou ambiental; pôr uma marca no produto; industrializá-lo em forma de biscoitos de arroz ou bolachas de arroz; arroz com sabores; arroz pré-pronto; e outras inovações. O mesmo autor assinala, ainda, que a tendência mundial é que a matéria-prima represente cada vez menos no valor agregado dos produtos que o consumidor adquire. Ou seja, a industrialização é que propicia a agregação de valor ao produto.

O IBD (Instituto Biodinâmico, 2006), único certificador brasileiro reconhecido na Europa, nos Estados Unidos e no Japão, contabiliza três organizações certificadas no estado do Rio Grande do Sul: a Fazenda Capão Alto das Criúvas, em Sentinela do Sul; a Agroparr Alimentos - marca comercial All Pure Rozcato -, também em Sentinela do Sul; e a Santa Lúcia Alimentos S.A. - marca comercial Blue Ville -, em Camaquã. No Brasil, existem outros 18 projetos certificados.

\section{História da Fazenda Capão Alto das Criúvas}

O local onde se fez o estudo de caso é uma propriedade agrícola familiar localizada no município de Sentinela do Sul, no Rio Grande do Sul. Desde 1983, a propriedade se dedica à produção de alimentos saudáveis baseados no princípio da agricultura biodinâmica.

O solo e o clima adaptam-se especialmente ao cultivo de arroz irrigado e à criação de bubalinos. Além disto, são criados bovinos, ovinos, eqüinos, suínos e são cultivadas eventualmente lavouras de milho, soja, trigo, batata doce e mandioca. A horta, o pomar e o gado leiteiro abastecem a família do empreendedor e os funcionários, que continuamente trabalham para ampliar a biodiversidade da paisagem local, procurando despertar o interesse da comunidade e agricultores da região pelas questões ambientais. Para eles, a paisagem é um ponto fundamental para a biodiversidade e o equilíbrio da produção, por isso preservam $35 \%$ da área total da fazenda com cobertura de mata nativa.

Há aproximadamente 50 anos, quando o pai do atual proprietário comprou a fazenda, que possui aproximadamente 567 hectares, tem início esse comportamento: já naquela época, se começou a proteger a natureza. O entrevistado descreve como isso era visto: "[...] meu pai era visto como louco na região porque plantar árvore naquela época em que todo mundo estava queimando [...] e ele começando a fazer florestas, nos anos 50 e $60[\ldots]$ isso estava na contramão de tudo".

$\mathrm{Na}$ realidade, essas preocupações vieram com o estudo da antroposofia e da obra de Rudolf Steiner, pesquisador que trouxe alguns elementos da antroposofia para a agricultura. Em 1924 acontece o primeiro movimento de agricultura ecológica do mundo. Segundo o entrevistado, a agricultura biodinâmica "[...] foi o primeiro impulso de proteger a natureza. Até então, ninguém se preocupava em proteger a natureza, porque não precisava". No entanto, como essa proposta estava atrelada a uma visão espiritual da atuação cósmica sobre as plantas, foi rechaçada na época, período da Primeira e da Segunda Guerra Mundial.

Apesar de o pai do proprietário ter estudado muito a antroposofia, não a colocou em prática, somente fazia a proteção da mata nativa. Tendo formação em Agronomia e um contato muito próximo com o pesquisador Lutzenberger, ambientalista mundialmente reconhecido, o proprietário da fazenda assumiu o seu comando em 1983, após oito anos de arrendamento para terceiros que utilizavam 'agricultura química'. O entrevistado relembra que "[...] a área de arroz ficou totalmente tomada de arroz preto e vermelho e a montanha já não tinha mais formação de pasto, tanto era o uso de herbicida na lavoura de soja.”. E existia uma série de dificuldades iniciais: "[...] durante três anos eu usei herbicida no banhado porque eu não sabia como fazer. Tinha financiamento do Banco do Brasil, sem capital nenhum, numa área grande... e já no quarto ano a gente começou a fazer o arroz sem usar agrotóxico". 
O entrevistado partiu da premissa de que, para se fazer agricultura orgânica, teria de fazer rotação de culturas. Começou, então, a plantar, na região do banhado, soja e milho. Ao tentar fazer isso, ia totalmente contra a aptidão do banhado, porque, conforme o empreendedor "[...] ele quer ser úmido no inverno e verão [...] e foi dominando e agredindo o banhado, até aqui, que conseguiram fazer agricultura. [...] Então, quando eu planto soja e milho aqui, o banhado me mostra que tem mais força que eu". Nesse momento, ele afirma ter passado por um processo de aprendizagem que, em alguns momentos, lhe gerou perdas, mas propiciou um resultado interessante. Ao plantar arroz nessa região, com conhecimentos adquiridos em conversas com antigos produtores italianos da serra, já no primeiro ano pôde colher numa área que estava totalmente inçada (com ervas invasoras), sem usar herbicida nem adubo. Nesse sentido, Filion (1999) destaca que uma das características dos empreendedores é que, por serem visionários, ficam motivados a aprender. O autor destaca, ainda, que, em geral, eles gostam de aprender em contato direto e trabalhando com matéria concreta.

O elemento central do trabalho da fazenda, segundo o empreendedor, é o homem, o responsável pelo organismo agrícola. É a essência de seu olhar, a faculdade de perceber situações, a capacidade de fazer um julgamento e agir que resultam no sucesso de uma propriedade e na sua durabilidade. É indispensável que o responsável adquira um sentido vivo, um conhecimento da vida e das forças que agem sobre ela, possibilitando, desse modo, uma paisagem integrada à produção de alimento. Tudo na fazenda é semeado a mão, e existe um cuidado diário com as lavouras, uma observação constante a todos os movimentos da natureza.

Todos que trabalham na fazenda são funcionários, e existe o projeto de se mudar a organização de trabalho para uma associação ou uma cooperativa. Todos os funcionários moram próximos à fazenda, possuem casa própria $\mathrm{e}$ têm espaço para fazer sua horta. Podem também levar o arroz e o leite da fazenda para subsistência.

Nesse sentido, Filion (1999) tem importante contribuição que se alinha ao discurso do empreendedor aqui citado. Por terem desenvolvido uma visão de longo prazo, empreendedores selecionam empregados que poderão progredir com eles ao longo do tempo. Assim, eles buscam manter seus recursos humanos por anos a fio e expressam alto nível de satisfação com seus colaboradores. Estes, mais que simplesmente desempenhar tarefas, estão reunidos em torno de um contrato psicológico no qual o respeito mútuo e a lealdade crescem ao longo do tempo. O processo de empreendedorismo é envolvente e total, tanto para o próprio empreendedor quanto para os colaboradores próximos que ele emprega para ajudar a tornar sua visão realidade.

A seguir apresenta-se o principal produto comercializável da fazenda, o arroz.

\section{Arroz Biodinâmico Volkmann}

O Arroz Biodinâmico Volkmann é o principal produto da fazenda, certificado desde outubro de 1999 pelo Instituto Biodinâmico de Desenvolvimento Rural (IBD) nos padrões DEMETER, selo reconhecido mundialmente pelo mais alto nível entre as normas de agricultura orgânica exigidas em suas diretrizes. As principais exigências da certificação IBD (2006) são: desintoxicação do solo; não utilização de adubos químicos e agrotóxicos; atendimento às normas ambientais do Código Florestal Brasileiro; recomposição de matas ciliares, preservação de espécies nativas e mananciais; respeito às normas sociais baseadas nos acordos internacionais do trabalho; bem-estar animal; envolvimento com projetos sociais e de preservação ambiental.

Da produção total, que se aproxima das 1,5 mil toneladas, a organização tem como meta exportar 30\%, sendo atualmente os seus principais clientes no exterior os mercados do EUA e Alemanha. Ferreira et al. (2005b) destacam, em artigo elaborado na mesma organização, que o empreendedor não pretende ampliar este mercado, pois a busca por maiores fatias de mercado lhe obrigaria a extrapolar a capacidade produtiva da propriedade, $\mathrm{o}$ que seria contrário aos princípios da filosofia biodinâmica. No mesmo artigo, são mencionados alguns aspectos da concorrência. São citados alguns produtores que seriam expressivos - denominados pelo empreendedor como colaboradores e não como concorrentes - na Itália, na Índia, no México e na Argentina - a estes dois últimos, ele presta consultorias como membro do Instituto Biodinâmico (IBD). Em termos nacionais, foi apontada uma iniciativa no Paraná, também realizada com a sua colaboração. 
São cultivadas, atualmente, quinze variedades de arroz - o do tipo 'agulhinha' é o mais vendido. Todas são produzidas sem agrotóxicos, adubos químicos ou conservantes. $\mathrm{Na}$ lavoura, são aplicados de forma homeopática os chamados 'preparados biodinâmicos', já citados neste trabalho. Estes preparados são elaborados a partir de cristais e plantas medicinais -, constituem uma fitoterapia para que as plantas cumpram melhor sua função e, no alimento, isto se reverta para o homem. Outra prática adotada pelo produtor é o preparado de 'chifre-esterco': elaborado por meio de esterco fresco de vaca, favorece a vivificação do solo; o preparado de 'chifre-silica' é feito de cristais de quartzo e atua na qualidade de frutos e sementes. Segundo o entrevistado: "[...] apesar de nenhuma agricultura conseguir fazer mais fotossíntese nas plantas [...], dentro do paradigma da ciência atual, esses processos que nós fazemos nunca poderiam ser pensados".

De acordo com o empreendedor, para que seu produto seja de qualidade, não pode ter agrotóxico, pois o consumidor acaba tendo de consumi-lo também. Ao mesmo tempo, esse produto não pode agredir o meio ambiente, para não deteriorar o lugar onde vai ser produzido. Além disso, esse alimento necessita ter uma força, para que ele realmente forneça energia para quem o consome, o que não seria possível com a utilização de produtos químicos. Essa preocupação com a qualidade de vida do consumidor e com a preservação da natureza demonstra um grande alinhamento com o desenvolvimento sustentável, conforme Daroit e Nascimento (2004).

A armazenagem é feita com o produto em casca, com controle de temperatura e umidade, dispensando o uso de inseticidas. No princípio, o arroz era feito em casca e vendido para o comércio convencional. Depois de um tempo, foi possível colocar um secador e um silo próprio na fazenda. Há quatro anos, eles possuem também o engenho próprio, beneficiam, empacotam e vendem o arroz. Como salienta o entrevistado, "[...] nesses quatro anos estamos aprendendo a vender nosso produto, com o consumidor. Assim como nós aprendemos com a natureza a fazer o arroz [...]". Como exemplo desse processo de aprendizagem, começaram comercializando o produto em uma embalagem de papel. No entanto, o padrão brasileiro é o plástico transparente. Logo, não tiveram sucesso de vendas porque a marca não era conhecida e se desconhecia qual produto a embalagem trazia. O empreendedor reconhece que talvez hoje alguns clientes comprassem, uma vez que já conhecem a marca e o produto.

A partir de 2002, os pacotes de $1 \mathrm{~kg}$ começaram a ser embalados também a vácuo, uma das formas de controlar os gorgulhos do arroz, que ocorrem naturalmente em grãos não tratados quimicamente. $\mathrm{O}$ empreendedor percebeu "que é uma coisa que choca um pouco", pois não é muito comum. Entretanto, esse processo é fundamental para a conservação e a durabilidade do arroz integral, pois, em contato com o oxigênio, pode oxidar.

Outra demanda do consumidor foi a retirada da pedra do arroz, visto que todas as empresas de arroz convencional trabalham atualmente dessa forma e o consumidor acostumou-se a ter o produto já limpo. Em virtude disso, o empreendedor tomou a seguinte medida: "fui no ferro velho conseguir uma máquina de trigo pra tirar pedra e adaptar pro arroz porque não tinha dinheiro pra comprar um equipamento grande".

Atualmente, a fazenda comercializa o arroz através de pedidos na internet, utilizando o envio pelo correio ou por transporte de cargas. O produto é vendido a granel para todo o Brasil, em sacas de $30 \mathrm{~kg}$ ou em pacotes de $1 \mathrm{~kg}$, em caixas com 10 unidades. O produtor afirma que o preço do frete praticamente iguala-se ao do produto. Percebe-se que existe um gargalo na logística.

Além disso, o produto é comercializado em mercados locais. O entrevistado conta que, no inicio, nenhum mercado queria expor seu produto. Decidiu, então, dar algumas amostras grátis para que fossem distribuídas às 'donas de casa'. A medida que elas foram conhecendo e gostando do produto, passaram a exigir que os mercados o tivessem disponível.

Assim, a divulgação dessas práticas é um dos trabalhos desenvolvidos na fazenda, assunto de que se tratará a seguir. 


\section{O compromisso de difusão da Biodinâmica}

Um dos compromissos assumidos pelo empreendedor, e que faz parte de sua filosofia de vida, é difundir as práticas da agricultura biodinâmica. Há quase vinte anos são feitos cursos anualmente na fazenda. Como os 'preparados biodinâmicos' têm de ser feitos em duas épocas do ano, primavera e outono, nesses momentos realizam-se os cursos. Normalmente, de acordo com o empreendedor, as pessoas acabam participando duas ou três vezes dos cursos, porque se necessita de muita prática para o aprendizado. Entretanto, algumas vezes acontece de, apesar de se fazer o curso e achá-lo muito interessante, não se conseguir colocá-lo em prática nas fazendas. Em média, por ano, a fazenda recebe mais de 400 visitantes.

O empreendedor citou ainda o caso de uma palestra que proferiu em Torres, cidade do estado do Rio Grande do Sul, para produtores convencionais, que não conseguiram acreditar que a lavoura 'ficasse limpa' (sem ervas invasoras) sem o uso de agrotóxicos. Inclusive não acreditaram nos níveis de produtividade, que são muito mais altos no biodinâmico. No Rio Grande do Sul, a média de produtividade estaria em torno de $5.912 \mathrm{~kg} / \mathrm{ha}$ (CONAB, 2006) para os agricultores convencionais, enquanto os biodinâmicos alcançam em torno de 7.500 $\mathrm{kg} / \mathrm{ha}$. Segundo o entrevistado: "no longo prazo, sempre o orgânico vai produzir mais do que o convencional [...] o convencional dá alguns picos de produtividade, mas também dá picos baixos [...]. Então esse é um tabu que tem que ser quebrado".

Para o entrevistado, "invariavelmente, o pessoal do convencional vê isso como o único caminho possível". O impedimento que essas pessoas colocam para ainda não ter mudado do convencional para o orgânico ou para o biodinâmico estaria "dentro da sua mente, porque a natureza está aí para a gente aprender a trabalhar com as forças dela".

O empreendedor acredita que, apesar de esse ser um processo que ocorrerá de forma lenta, o agricultor tende, cada vez mais, ao orgânico, até mesmo por uma necessidade, em geral, econômica. Ele observa, no entanto, que o consumidor está mais atrasado que o produtor, no sentido de não valorizar a importância da preservação do meio ambiente e da saúde humana, preferindo muitas vezes o que é mais conveniente e cômodo. Por outro lado, existe uma forte pressão da indústria agroquímica, pois "todos esses produtos industrializados que são trazidos para o agricultor levam muita renda para a cidade". Com a agricultura convencional, o produtor tornase extremamente dependente da indústria. Entretanto, todos os preparados biodinâmicos são feitos pelo próprio agricultor, a um custo baixo, tornando-o independente da indústria de insumos, conforme destaca Navarro (2001).

O entrevistado salienta, também, que a grande diferença da agricultura biodinâmica é que ela começa a dar uma visão de longo prazo ao agricultor, acostumado a trabalhar para pagar dívidas ao banco: "Tu podes saber como vai ser daqui a 15 anos [...], por exemplo, vai ter uma árvore ali daquele tamanho [...]. Então tu começas a enxergar um trabalho de mais longo prazo". Essa visão de longo prazo, embasada nos valores desse empreendedor, influencia sobremaneira as atividades da organização, e esta lhe permite colocar em prática sua visão e seus valores.

Com as passagens destacadas até o momento, podem-se encontrar no empreendedor citado alguns traços identificados por Egri e Herman (2000) em seu conceito de 'liderança ambiental': a habilidade de influenciar indivíduos e mobilizar organizações a realizar uma visão de sustentabilidade a longo prazo.

A seguir efetua-se uma análise a respeito de algumas inovações e do papel do empreendedor orientado para a sustentabilidade nesse processo.

\section{Análise das inovações e do papel do empreendedor orientado para a sustentabilidade}

Basicamente, os custos da fazenda se concentram na manutenção das máquinas, na mão-de-obra e na comercialização. Não existe um centro de custo especifico para a pesquisa e o desenvolvimento de inovações. Uma das fontes de idéias é a participação em feiras nacionais e internacionais, nas quais se buscam algumas 
soluções prontas. Nesse caso, basicamente o que é feito são replicações de tecnologias. O entrevistado citou o exemplo da utilização de marrecos na lavoura por um produtor alemão que conheceu em uma dessas feiras. Este produtor o faz com o intuito de preparar o solo, dispensando o emprego do trator, veículo altamente poluente e impactante no meio-ambiente.

Além disso, o empreendedor vê a natureza como fonte de inovações, pois ela impõe algumas limitações e necessidades que o impelem ao desenvolvimento de soluções. Elas acontecem de forma espontânea e são observadas pelo entrevistado:

Eu me apaixono pelos segredos da natureza [...] desvendar os segredos da natureza é a maior busca que eu tenho. Enquanto eu estou fazendo isso, está saindo um produto que está sendo vendido no mercado, que faz girar a fazenda e dá suporte ao empreendimento. A minha força de vontade está realmente direcionada à pesquisa... eu tenho essa intenção de poder desvendar o conhecimento nessa direção de aprender com a natureza.

O problema específico do banhado de não comportar o cultivo de milho e soja, citado anteriormente, é um exemplo prático dessa observação. $\mathrm{O}$ entrevistado conta que, se naquele momento quisesse uma solução mais prática, buscaria a utilização de agroquímicos. No entanto, como a sua busca vai além da preocupação econômica de curto prazo, esperou a natureza the mostrar o melhor caminho.

Entretanto, ele vê como o principal motivador e a principal fonte de inovações o próprio consumidor. Isso se traduz numa constante busca por uma qualidade excelente, não somente em termos de qualidade e de conveniência do produto, mas também em termos energéticos, que se constitui no diferencial da biodinâmica. As mudanças de embalagem - transparente e a vácuo -, no processo - retirada de pedras e impurezas - e na comercialização - busca por novos canais - são exemplos de inovações que foram impulsionadas pelas necessidades dos clientes.

Outra questão, ligada mais a aspectos de gestão da fazenda, está estritamente relacionada aos princípios pregados pela biodinâmica. O projeto de mudança da estrutura de gestão da fazenda para uma forma associativa ou cooperativa corresponde à noção de que tudo é um organismo vivo e que os seres vivos (vegetais, animais, o homem e o solo) são sensíveis à qualidade dos sentimentos, pensamentos e ações que se desenvolvem num ambiente. Por isso, para o empreendedor, "é fundamental cultivar relações de confiança e de cooperação".

No Quadro 2, resume-se como as características do empreendedor, segundo De Klerk e Kruger (2006), Filion (2000) e Rodrigues e Vieira (2004), conforme apresentadas no referencial teórico, são observadas no caso estudado. É interessante ressaltar que estas características se diferenciam no presente caso, em relação a outros casos de empreendedorismo, justamente pela orientação para o desenvolvimento sustentável seguida pelo empreendedor estudado.

\section{Quadro 2: Características observadas no caso estudado em relação aos elementos teóricos}

\begin{tabular}{ll}
\hline $\begin{array}{l}\text { Características definidas } \\
\text { em De Klerk e Kruger } \\
\text { (2006) }\end{array}$ & Características observadas no caso estudado \\
\hline Prontidão & $\begin{array}{l}\text { O empreeendedor é uma pessoa extremamente dinâmica, sempre disposta a agir } \\
\text { em favor do seu empreendimento. }\end{array}$ \\
\hline Visão do Futuro & $\begin{array}{l}\text { Busca o desenvolvimento de longo prazo do negócio e da fazenda, "ver a árvore } \\
\text { crescer e se desenvolver". }\end{array}$ \\
\hline Capacidade de Assumir & $\begin{array}{l}\text { Decisão por fazer uma fazenda orgânica, tendo assumido a fazenda com dívidas } \\
\text { e com problemas graves de solo. }\end{array}$ \\
\hline Riscos & O empreendedor buscou financiamento bancário. \\
\hline Capital Suficiente & $\begin{array}{l}\text { Adquiriu o aprendizado ao longo do tempo. No começo, não sabia como } \\
\text { trabalhar, da forma como queria, as diversas variáveis ambientais. }\end{array}$ \\
\hline Conhecimento Suficiente
\end{tabular}




\begin{tabular}{|c|c|}
\hline Discernimento & $\begin{array}{l}\text { Percebeu como uma oportunidade a necessidade ambiental ligada a um nicho de } \\
\text { mercado. }\end{array}$ \\
\hline Criatividade e Inovação & $\begin{array}{l}\text { Em diversas situações teve de usar a criatividade para não incorrer em novos } \\
\text { investimentos ou custos, principalmente no desenvolvimento de maquinário e } \\
\text { no manejo de animais e plantas. }\end{array}$ \\
\hline Ambição & $\begin{array}{l}\text { Focada não absolutamente no sentido financeiro, mas em ter projetos de } \\
\text { expansão, com o intuito de desenvolver mais produtores que sigam sua } \\
\text { filosofia. }\end{array}$ \\
\hline Firmeza e Determinação & $\begin{array}{l}\text { Convicção nas próprias ações e na filosofia que segue, gerenciando o negócio e } \\
\text { influenciando funcionários e outros produtores. }\end{array}$ \\
\hline Dedicação & $\begin{array}{l}\text { Sua vida é o empreendimento, desde o acordar às 05:00 para pegar o primeiro } \\
\text { raio de sol e realizar as atividades biodinâmicas, e assim viver os } 365 \text { dias do } \\
\text { ano, sem férias. }\end{array}$ \\
\hline Valor(es) & $\begin{array}{l}\text { Valores bastante consolidados, baseados na filosofia de Rudolf Steiner } \\
\text { (antroposofia) e no convívio que teve com o renomado ambientalista } \\
\text { Lutzemberger. }\end{array}$ \\
\hline Adaptabilidade & $\begin{array}{l}\text { Mostra-se flexível para se moldar à nova situação e desenvolver o negócio } \\
\text { segundo a nova filosofia seguida. }\end{array}$ \\
\hline Recompensa & $\begin{array}{l}\text { Considera como principal recompensa o fato de conseguir fornecer este produto } \\
\text { aos clientes (que acredita ser benéfico à saúde) e de desenvolver mais } \\
\text { produtores que acreditem nesta filosofia. }\end{array}$ \\
\hline $\begin{array}{l}\text { Características definidas } \\
\text { em Filion (2000) }\end{array}$ & Características observadas no caso estudado \\
\hline $\begin{array}{l}\text { Valores e cultura de } \\
\text { empreendedorismo } \\
\text { adquiridos por meio de } \\
\text { contato com, pelo menos, } \\
\text { um modelo empreendedor } \\
\text { durante a juventude }\end{array}$ & $\begin{array}{l}\text { O pai do empreendedor era tambem empreendedor, e mesmo em tempos em que } \\
\text { as questões ambientais não eram consideradas, já desenvolvia ações pró meio- } \\
\text { ambiente. }\end{array}$ \\
\hline Experiência em Negócios & $\begin{array}{l}\text { Trabalhou em empreendimentos como agrônomo que não envolviam as } \\
\text { variáveis do meio-ambiente. }\end{array}$ \\
\hline Diferenciação & $\begin{array}{l}\text { O tipo de produto comercializado tem diferencial ainda não tão valorizado no } \\
\text { mercado nacional, mas bastante no mercado externo. }\end{array}$ \\
\hline Intuição & Busca seguir seus instintos ao lidar com a natureza. \\
\hline Envolvimento & $\begin{array}{l}\text { Envolve-se com todas as etapas do processo, se certificando de que ao longo } \\
\text { dele a filosofia seja seguida. }\end{array}$ \\
\hline $\begin{array}{l}\text { Liderança; controle sobre o } \\
\text { comportamento das } \\
\text { pessoas em redor e } \\
\text { capacidade de trabalho } \\
\text { incansável }\end{array}$ & $\begin{array}{l}\text { Líder bastante carismático, consegue envolver seus trabalhadores em torno do } \\
\text { projeto. }\end{array}$ \\
\hline Sonho realista (visão) & $\begin{array}{l}\text { Tem sonhos que, aos poucos, torna reais, com planejamento e organização; vê, } \\
\text { assim, a fazenda se desenvolver conforme sua filosofia. }\end{array}$ \\
\hline $\begin{array}{l}\text { Trabalho em rede com } \\
\text { moderação }\end{array}$ & $\begin{array}{l}\text { Sua atividade não é isolada, trabalha com diversas redes de biodinâmica no } \\
\text { mundo. }\end{array}$ \\
\hline $\begin{array}{l}\text { Sistema próprio de relações } \\
\text { com os empregados }\end{array}$ & $\begin{array}{l}\text { A relação com os funcionários transcende o profissional. Tem projetos de } \\
\text { transformar esse empreeendimento individual em uma cooperativa. }\end{array}$ \\
\hline $\begin{array}{l}\text { Aprendizagem com seus } \\
\text { próprios padrões }\end{array}$ & $\begin{array}{l}\text { Para o empreendedor, nao basta saber apenas o que está nos livros. Ele aprende } \\
\text { cada vez mais e com os próprios movimentos da natureza. }\end{array}$ \\
\hline $\begin{array}{l}\text { Características definidas } \\
\text { em Rodrigues e Vieira } \\
(2004)\end{array}$ & Características observadas no caso estudado \\
\hline Atividade empreendedora & al, $n$ \\
\hline
\end{tabular}


vinculada aos planos de vida da pessoa em sua energia para empreender projeto de vida do empreendedor, que mobiliza sua familia, seus funcionários e principalmente outros empreendedores interessados em adotar a biodinâmica como filosofia de vida e prática produtiva.

Entende-se que estas características observadas estão ligadas à persistência do empreendedor em seguir sua filosofia com rigor e dedicação, tendo uma visão de futuro orientadora. O desenvolvimento sustentável está no coração deste caso de empreendedorismo, o que leva os valores seguidos a conjugar o empreendimento com o projeto de vida do empreendedor, sendo difícil separá-los. A prática do dia-a-dia do empreendimento expõe em seus diversos processos a preservação ambiental e serve como um exemplo, a ser observado, de imersão e entrelaçamento do negócio com a noção de desenvolvimento sustentável.

\section{Considerações finais}

Confirmando a proposta de Shane e Ventakaraman (2000), o caso apresentado representa o empreendedorismo como a existência de oportunidades e a presença de pessoas empreendedoras. Apesar do fato de existir uma oportunidade de mercado vinculada à busca de produtos mais saudáveis pela população, nada disso seria possível sem a presença de um empreendedor convicto da importância do seu negócio para a sociedade. Logo, não se trata apenas de empreendorismo por necessidade - como acontece em grande número no Brasil -, mas por reconhecimento de oportunidades vinculadas a valores.

No Quadro 3, apresentam-se, de forma resumida, algumas das principais características do caso em estudo.

\section{Quadro 3: Resumo das principais características do caso estudado}

\begin{tabular}{|c|c|c|}
\hline Elemento & Característica & Referências \\
\hline $\begin{array}{l}\text { Cenário do Mercado de } \\
\text { Arroz Brasileiro }\end{array}$ & $\begin{array}{l}\text { - Mais importante alimento para a segurança alimentar no } \\
\text { mundo (FAO); } \\
\text { - Rio Grande do Sul é o maior produtor e industrializador } \\
\text { do Brasil; } \\
\text { - Necessidade de agregar valor ao arroz. }\end{array}$ & $\begin{array}{l}\text { - FAO (2006) } \\
\text { - Ludwig (2004) }\end{array}$ \\
\hline $\begin{array}{l}\text { História da Fazenda } \\
\text { Capão Alto das Criúvas }\end{array}$ & $\begin{array}{l}\text { - Cerca de } 50 \text { anos de existência; } \\
\text { - Desde } 1983 \text {, dedicada à produção de alimentos saudáveis; } \\
\text { - Visão de longo prazo, agregando funcionários engajados e } \\
\text { fiéis ao projeto. }\end{array}$ & - Filion (1999) \\
\hline $\begin{array}{l}\text { Arroz Biodinâmico } \\
\text { Volkmann }\end{array}$ & $\begin{array}{l}\text { - Principal produto da fazenda; } \\
\text { - Certificado desde outubro de 1999, pelo Instituto } \\
\text { Biodinâmico de Desenvolvimento Rural (IBD) nos padrões } \\
\text { DEMETER; } \\
\text { - 1,5 mil toneladas por ano, com uma meta de } 30 \% \text { de } \\
\text { exportação; } \\
\text { - Vendas pela internet e em mercados locais; } \\
\text { - Preocupação com qualidade de vida do consumidor e com } \\
\text { preservação da natureza. }\end{array}$ & $\begin{array}{l}\text { - Daroit e } \\
\text { Nascimento } \\
(2004) ; \\
\text { - IBD (2006) }\end{array}$ \\
\hline $\begin{array}{l}\text { Compromisso de difusão } \\
\text { da Biodinâmica }\end{array}$ & $\begin{array}{l}\text { - Há quase } 20 \text { anos são desenvolvidos cursos na fazenda } \\
\text { para difundir os conceitos da Biodinâmica; } \\
\text { - Palestras fora da fazenda; } \\
\text { - Liderança Ambiental. }\end{array}$ & $\begin{array}{l}\text { - Egri e Herman } \\
(2000)\end{array}$ \\
\hline
\end{tabular}


Análise das inovações e do papel do empreendedor orientado para a sustentabilidade
- Participação do empreendedor em feiras nacionais e internacionais para a troca de experiências e geração de idéias;

- As imposições da natureza forçam o empreendedor à geração de inovações para manter a produção sustentável (ex: problemas com o banhado);

- Impulso para as inovações vem também dos consumidores (ex: mudanças de embalagem, processo e comercialização).

De maneira geral, pode-se constatar que, pelas práticas de sustentabilidade da fazenda e suas inovações, perpassam questões meramente mercadológicas e de curto prazo. Essas práticas são conduzidas pelo empreendedor e estão envoltas pela filosofia embasada na biodinâmica. Ao mesmo tempo, são induzidas em alguns momentos por necessidades de mercado e da sociedade, o que confirma, de certa forma, a influência dos stakeholders (FREEMAN, 1984; HALL; VREDENBURG, 2003) nas práticas organizacionais. Já em outros momentos, são impulsionadas pela necessidade de se estabelecer um equilíbrio dentro da própria fazenda, vista como um 'organismo vivo' pelo empreendedor. Portanto, propõe-se, na Figura 1, um esquema interpretativo dessa atuação do empreendedor orientado para a sustentabilidade, baseado em suas características pessoais e filosofia de vida.

Figura 1: Empreendedor orientado para a sustentabilidade

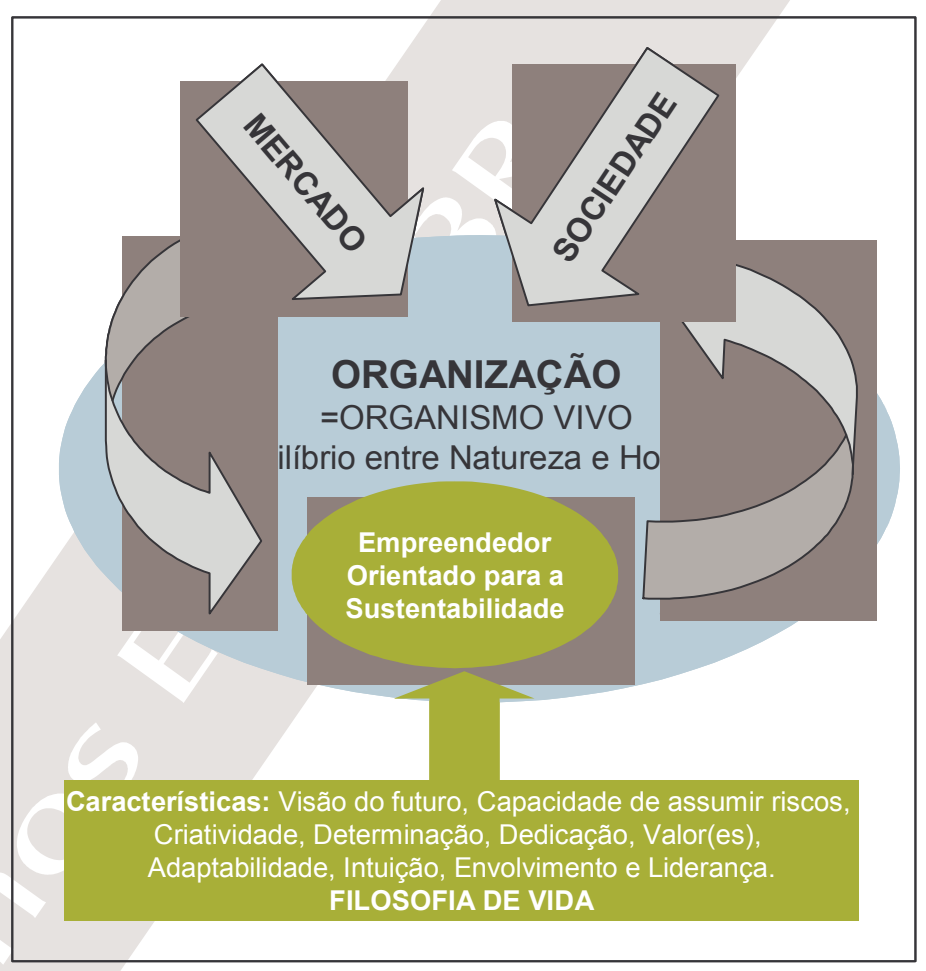

Logo, percebe-se que, nesse caso, a organização e o individuo não estão desconectados e que a filosofia de vida do empreendedor transpõe-se para as práticas organizacionais (RODRIGUES; VIEIRA, 2004). Talvez, por esse motivo, como expôs o entrevistado, algumas pessoas que entram em contato com experiências alternativas de agricultura têm certa dificuldade de colocá-las em prática. Esse tipo de agricultura exige uma profunda mudança de valores e uma real visão de longo prazo e da fazenda como um organismo vivo.

Além disso, a implantação de práticas ligadas à agricultura sustentável - biodinâmica, orgânica, entre outras depende muito das especificidades locais, influenciadas, sobremaneira, por fatores ambientais, culturais, sociais 
e econômicos. Isso torna difícil replicar experiências de sucesso. No curto prazo, uma solução oferecida pela indústria de insumos químicos pode parecer mais vantajosa, caso não haja uma mudança de valores do empreendedor. Esses fatores dificultam a difusão de práticas mais sustentáveis na agricultura. No entanto, o caso apresentado demonstra que é possível implementar inovações alinhadas com a sustentabilidade, desde que conduzidas por um empreendedor orientado para essa perspectiva.

Dessa forma, além de criatividade e liderança, atributos necessários e destacados por diversos autores, o empreendedor orientado para sustentabilidade deve possuir valores que estejam de acordo com essa perspectiva, somados a uma visão de longo prazo na condução das atividades da organização. Essa dimensão temporal amplia, dentro de seu contexto socioeconômico e ambiental, o papel da organização, que deixa de ser um empreendimento estabelecido para atender necessidades de curto prazo do empreendedor - assim como se assinala nos estudos do Global Entrepreneurship Monitor, 2006 - e passa a atender as necessidades da sociedade e do meio ambiente, no presente e no futuro. 


\section{Referências}

ALMEIDA, J. Da ideologia do progresso à idéia de desenvolvimento (rural) sustentável. In: ALMEIDA, J.; NAVARRO, Z. (Orgs.). Reconstruindo a agricultura: idéias e ideais na perspectiva do desenvolvimento sustentável. Porto Alegre: Editora da UFRGS, 1997.

ÁVILA, J. C. Princípios básicos do método biodinâmico. 2000. Disponivel em: <http://www.sab.org.br/agric-biod/principios.htm>. Acesso em: 20 jan. 2006.

BARATA, T. S. Caracterização do consumo de arroz no Brasil. In: CONGRESSO BRASILEIRO DE ECONOMIA E SOCIOLOGIA RURAL, XLIII, 2005, Ribeirão Preto. Anais do XLIII Congresso Brasileiro de Economia e Sociologia Rural. CD-ROM.

BARTHOLO, R. A mais moderna das esfinges: notas sobre ética e desenvolvimento. In: BURSZTTYN, M. (Org.) A difícil sustentabilidade. Rio de Janeiro: Garamond, 2001.

COMPANHIA NACIONAL DE ABASTECIMENTO - CONAB. Série histórica do arroz 2006 . Disponível em: <www.conab.gov.br/download/safra/ArrozSerieHist.xls>. Acesso em: 20 fev. 2006.

DAMANPOUR, F.; EVAN, W. Organizational innovation and performance: the problem of "organizational lag". Administrative Science Quaterly, n. 29, p. 392-409, 1984.

DAROIT, D.; NASCIMENTO, L. F. Dimensões da Inovação sob o Paradigma do Desenvolvimento Sustentável. In: ENCONTRO DA ASSOCIAÇÃO NACIONAL DE PROGRAMAS DE PÓS-GRADUAÇÃO EM ADMINISTRAÇÃO, 2004, Curitiba. Anais da ENANPAD, 2004.

DE KLERK, G. J.; KRUGER, S. The driving force behind entrepreneurship: an exploratory perspective. Disponivel em: $<$ http://www.kmu.unisg.ch/rencontres/band2002/F_04_deKlerk.pdf>.

Acesso em: 13 jun. 2006.

DEON, P. R. C. A informação na cadeia de abastecimento do arroz com transações de dois tipos de produtos: arroz commodity e arroz orgânico. 2002. Dissertação (Mestrado) -Universidade Federal do Rio Grande do Sul. Centro de Estudos e Pesquisas em Agronegócios. Programa de Pós-Graduação em Agronegócios, Porto Alegre, 2002.

EGRI, C. P.; HERMAN, S. Leadership in the North American environmental sector: values, leadership styles, and contexts of environmental leaders and their organizations. Academy of Management Journal, n. 43, v. 4, p. 571; Aug. 2000.

EMBRAPA ARROZ E FEIJÃO. Sistemas de Cultivo. Disponível em: http://www.cnpaf.embrapa.br/arroz/index.htm. Acesso em: 15 fev. 2006.

FELDMANN, F. A parte que nos cabe: consumo sustentável. In: TRIGUEIRO, André (Coord.). Meio ambiente no século 21. Rio de Janeiro: Sextante, 2003.

FERREIRA, G. et al. A segurança dos alimentos e a certificação nos acordos internacionais e no ordenamento jurídico brasileiro como fatores de competitividade: um caso na erva-mate. In: CLADEA, Santiago, 2005.

FERREIRA, G. et al. Análise das relações e transações entre produtor e agroindústria: o caso do arroz orgânico e biodinâmico no Rio Grande do Sul - Brasil. In: V International PENSA Conference on Agri-food Chains/Networks Economics and Management, $2005 \mathrm{~b}$.

FILION, J. L. Diferenças entre sistemas gerenciais de empreendedores e operadores de pequenos negócios. Revista de Administração de Empresas, v. 39, n. 4, out./dez. 1999.

. Empreendedorismo e gerenciamento: processos distintos, porém complementares. Revista de Administração de Empresas - Light, v. 7, n. 3, jul./set., 2000.

FOOD AND AGRICULTURE ORGANIZATION OF THE UNITED NATIONS. Agricultural Data Faostat. Disponivel em: <http://faostat.fao.org/faostat/collections?version=extCthasbulk=0\&tsubset=agriculturectlanguage=EN>. Acesso em: 24 fev. 2006.

FREEMAN, R. E. Strategic management: a stakeholder approach. Boston: Pitman, 1984.

GIL, Antonio Carlos. Métodos e Técnicas de Pesquisa Social. São Paulo: Editora Atlas, 1999. 
GLADWIN, T.; KENNELLY, J.; KRAUSE, T. Shifting paradigms for sustainable development: implications for management theory and research. Academy of Management Review, v. 20, n. 4, p. 874-907, 1995.

GLOBAL ENTREPRENEURSHIP MONITOR - GEM. Empreendedorismo no Brasil 2005: Relatório Executivo. Curitiba, 2006. Disponivel em: $<$ http://www.sebrae.com.br/br/aprendasebrae/empreendedorismo_brasil.asp>. Acesso em: 15 jun. 2006.

GODOY, A. S. Pesquisa Qualitativa: tipos fundamentais. Revista de Administração (RAE), São Paulo, v.35, n.2, p. 20-39, mai./jun. 1995.

HALL, J.; VREDENBURG, H. The challenges of innovating for sustainable development. Mit Sloan Management Review, p. 61-68, Fall 2003.

HAWKEN, P.; LOVINS, A.; LOVINS, H. Capitalismo natural: criando a próxima revolução industrial. São Paulo: Cultrix, 1999.

INSTITUTO BIODINÂMICO - IBD. Disponível em: <http://www.ibd.com.br>. Acesso em 24 fev. 2006.

INSTITUTO BRASILEIRO DE GEOGRAFIA E ESTATÍSTICA - IBGE. Produção agrícola municipal. Disponível em: <http://www.ibge.gov.br/>. Acesso em: 15 fev. 2006.

JACOBSON, R. The "Austrian" School of Strategy. Academy of Management Review, v. 17, n. 4, p. 782-807, Oct. 1992.

JO, H.; LEE, L. The relationship between an entrepreneur's background and performance in a new venture. Technovation, v. 4, n. 16, p. 161-171, 1996.

KHATOUNIAN, C. A. A reconstrução ecológica da agricultura. Botucatu, SP: Agroecológica, 2001.

KLEIN, K. J.; SORRA, J. S. The challenge of innovation implementation. Academy of Management Review, v. 21, n. 4, p. 1055,0 ct. 1996.

LAFUENTE, A.; SALAS, V. Types of entrepreneurs and firms: the case of new spanish firms. Strategic Management Journal, n. 1, v. 10, Jan./Feb. 1989.

LUDWIG, V.S. A agroindústria processadora de arroz: um estudo das principais características organizacionais e estratégicas das empresas líderes gaúchas. 2004. Dissertação (M.S.) - Universidade Federal do Rio Grande do Sul, Porto Alegre, 2004.

LUMPKIN, G. T.; DESS, G. G. Clarifying the entrepreneurial orientation construct and linking it to performance. Academy of Management Review,v. ?, n. ?, p. 135, Jan. 1996.

LUTZENBERGER, J. A. 0 absurdo da agricultura. Estudos Avançados, n. 43, set./dez, São Paulo: USP, 2001.

MACHADO. H. V.; ST-CYR, L.; MIONE, A.; ALVES, M. C. M. O processo de criação de empresas por mulheres. Revista de Administração de Empresas - eletrônica, v. 2, n. 2, jul./dez. 2003.

MACHLINE, Claude. Inovação, gestão e decisão tecnológicas na indústria alimentícia brasileira. Revista de Administração de Empresas, v. 3, n. 18, p. 57-82, jul./set. 1978.

MALHOTRA, N. K. Pesquisa de marketing: uma orientação aplicada. 3. ed. Porto Alegre: Bookman, 2001, 719p.

MILLER, W.; MORRIS, L. 4th. Generation R\&D: managing knowledge, technology and innovation. New York: John Wiley \&t Sons Inc., 1999.

NAVARRO, Z. Desenvolvimento rural no Brasil: os limites do passado e os caminhos do futuro. Estudos Avançados, n. 43, set./dez., São Paulo: USP, 2001.

PATERNIANI, E. Agricultura sustentável nos trópicos. Estudos Avançados, n. 43, set./dez., São Paulo: USP, 2001.

PEDROZO, E. A.; SILVA, T. N.; TAKITANE, I. C. O Seikatsu Club: imbricamento entre redes sociais, segurança dos alimentos, sustentabilidade e o processo institucional no Japão. Revista Eletrônica de Administração - Read, 39. ed., v. 10, n. 3, maio/jun. 2004.

PENROSE, E. The theory of the firm growth. Oxford: Basil Blackwell, 1959.

RIMOLI, C. A. et al. Reflexões sobre empreendedorismo: estudo de casos de empresas de sucesso e insucesso. In: ENCONTRO DA ASSOCIAÇÃO NACIONAL DE PROGRAMAS DE PÓS-GRADUAÇÃO EM ADMINISTRAÇÃO, Curitiba: Anais da ENANPAD, 2004. 
RODRIGUES, P. H. M. e VIEIRA F. R. C. A Mediação Sociocultural na Ação Empreendedora: Por um Plano de Vida que Anteceda o Plano de Negócios. In: ENCONTRO DA ASSOCIAÇÃO NACIONAL DE PROGRAMAS DE PÓS-GRADUAÇÃO EM ADMINISTRAÇÃO, Curitiba: Anais da ENANPAD, 2004.

SACHS, I. Brasil rural: da redescoberta à invenção. Estudos Avançados, n. 43, set./dez., São Paulo: USP, 2001.

Caminhos para o desenvolvimento sustentável. Rio de Janeiro: Garamond, 2002.

Desenvolvimento: includente, sustentável, sustentado. Rio de Janeiro: Garamond, 2004.

SALES, A. H. L; SOUZA NETO, S. P. Empreendedorismo nas micro e pequenas empresas no Brasil. In: ENCONTRO DA ASSOCIAÇÃO NACIONAL DE PROGRAMAS DE PÓS-GRADUAÇÃO EM ADMINISTRAÇÃO, Curitiba: Anais da ENANPAD, 2004.

SCHUMPETER, J. A. Capitalismo, Socialismo e Democracia. Rio de Janeiro: Fundo de Cultura, 1934.

SHANE, S. Is the independent entrepreneurial firm a valuable organizational form? Academy of Management Journal, p. $110,1995$.

SHANE, S.; VENTAKARAMAN, S. The promise of entrepreneurship as a field of research. Academy of Management Review, v.25, n.1, p. 217-226, 2000.

SOUZA DUTRA, I. Ambiente Empreendedor e a Mortalidade Empresarial: Estudo do Perfil do Empreendedor da Micro e Pequena Empresa no Norte do Paraná. In: ENCONTRO DA ASSOCIAÇÃO NACIONAL DE PROGRAMAS DE PÓS-GRADUAÇÃO EM ADMINISTRAÇÃO, Curitiba: Anais da ENANPAD, 2004.

STAKE, Robert, E. Case Studies. In: DENZIN, Norman K.; LINCOLN, Yvonna S. (Ed.). Handbook of Qualitative Research. Califórnia: Sage, 2000. p.435-455.

TRIVIÑOS, A. Introdução à pesquisa em Ciências Sociais. São Paulo: Atlas, 1987.

VEIGA, J. E. O Brasil rural ainda não encontrou seu eixo de desenvolvimento. Estudos Avançados, v. 15, n. 43, São Paulo: USP, dez. 2001. WORLD COMISSION ON ENVIROMENT AND DEVELOPMENT. Our common future. New York: Oxford University Press, 1987.

YIN, R. K., Estudo de Caso: planejamento e métodos. 2. ed. Porto Alegre: Bookman, 2005. 205p.

${ }^{1}$ O GEM - Global Entrepreneurship Monitor - é uma pesquisa internacional liderada pela London Business School e o Babson College (EUA). Tem como proposta avaliar o empreendedorismo no mundo com base em indicadores comparáveis. Desde 1999, quando realizou seu primeiro ciclo, até hoje, o estudo envolveu mais de 40 países de todos os continentes e dos mais variados graus de desenvolvimento econômico e social, tornando-se a investigação de maior escopo em sua área. O Brasil participa do GEM desde 2000.

${ }^{2}$ Empreendedores iniciais são aqueles cujos empreendimentos têm até 42 meses de vida, período que a literatura considera capital para a sobrevivência de um empreendimento. 